\title{
Ourense, Auria
}

\section{Ourense, Auria}

\author{
Xosé Carlos Caneiro \\ https://doi.org/10.17979/aarc.2007.1.0.5015
}

Señoras y señores, buenos días. Permítanme en primer lugar darles la bienvenida, significar nuestro orgullo por acogerlos en Ourense.

Ourense, a quien don Eduardo Blanco Amor denominaba Auria.

Cada vez que hablo de esta ciudad hechizada, viene a mí - ignoro el motivo- el magno Valle-Inclán. Repito, ignoro el motivo. Tal vez porque el genio pronunciara una sentencia que a menudo utilizo para referirme a mi ciudad: «Las cosas no son como las vemos sino como las recordamos». Y Ourense es una ciudad para recordar.

Quizá se trate de un abismo. En ocasiones, atrae. Y otras, las menos, empuja hacia otros círculos. Ourense, con sus ciento quince mil habitantes, es el gran abismo de la geografía galaica y el lugar olvidado que nadie debe olvidar. Me explico. Ourense, a quién llamamos Auria, no goza de buena salud en los índices financieros; aparece apartada de las grandes nóminas de éxitos económicos, alejada de las rentas acomodadas de otras ciudades del norte. Todo esto. Y no obstante, posee el encanto de las cosas prohibidas, su atracción y su hechizo, la prisión de la fantasía.

Nadar ríos de Ourense salva al viajero. Porque se desconoce. En todo lo desconocido hay siempre una gran parte de seducción. El mundo está escrito en las venas de este territorio amado como en un espejo. La historia del mundo, quiero decir. Aquí convivieron romanos y árabes y suevos e incluso nosotros, tribu actual que uno no sabe muy bien hacia dónde dirige sus pasos frenéticos, hacia dónde camina.

Auria, para ser conocida y gozada, necesita un Stephen Dedalus que acompañe los pasos del viajante. Dedalus o Virgilio, quien conduce a Dante en su viaje a ultratumba. A este último, no obstante, no lo quiero erigir en protagonista. Ourense, que a veces tiene mucho de infierno, no deja de ser una ciudad plena de paraísos. La soledad. La ciudad vieja con su luz única y su piedra balsámica. La soledad. El agua alquímica en sus entrañas. La soledad. Los monumentos de escasa fama y enorme talento. Los seres que transitan cada día sus venas de neón $\mathrm{y}$ alivio.

Ustedes, sin duda, quedarán atrapados en el balcón del casco antiguo, auténtico mirador para conocer, de verdad y sin fisuras, esta Auria complaciente
Good morning, ladies and gentlemen. Let me first of all welcome you and tell you that I am proud to have you here in Ourense.

Ourense, the city called Auria by Mr. Eduardo Blanco Amor.

Every time I talk about this haunted city, I recall the famous Valle-Inclán, I don't know why. I repeat that I don't know why. Maybe because the genius uttered a sentence that I often quote in order to refer to my city: "Things are not the way they are, but the way we remember them». And Ourense is a city to remember.

Maybe it is an abyss. Sometimes it appeals to you, on other less frequent ocasions; it pushes you to other circles. Ourense, with one hundred and fifteen thousand inhabitants, is the great abyss of Galician geography and the forgotten place that nobody should forget. I mean, Ourense, also called Auria, does not have a good financial standing. It does not share those huge payrolls of financial success, it is far away from the well-off accounts of other Northern cities. All of this is true, however, it possesses the charm of forbidden things, their appeal and spell, the prison of fantasy.

Swimming the rivers of Ourense saves the traveller because it is unknown. Everything which is unknown is also seductive to a great extent. The world is written in the veins of this beloved territory as in a mirror. I mean, the world history. Romans, Arabs and Swabians lived here together. Even us, the current tribe which does not exactly know where it is heading with frenzied steps.

Auria, needs a Stephen Dedalus in order to be known and loved, somebody guiding the traveller's steps. Dedalus or Virgil, who led Dante in his journey to the nethermost. Nevertheless, I would not like to turn the latter into the main character. Ourense, which sometimes seems a lot like hell, remains a city full of paradises: loneliness; the old quarter with its unique light and its soothing stone; loneliness; the alchemy water in its bosom; loneliness; the scarcely - known and hugely - talented monuments; the people walking daily through its veins of neon and relief.

You will undoubtedly remain trapped in the veranda of the old quarter, a true lookout from where to get to 
know, truly and seamlessly, this pleasant and affable Auria. It creates an evocative atmosphere stone by stone, a warm atmosphere on foggy days, a refreshing one when the sunshine bothers you, a sleepy one if you are looking for some peace and quiet. It builds its future stone by stone among the figures and fineness and fictions treasured by the cathedral: Jesus Christ growing his hair, a deafening silence, and mysterious stained-glass windows as in one of Edgar Allan Poe's tales. Stone by stone, it bathes itself in the hot water of the Burgas, that unexplored mystery sprouting from the deep city which sometimes rewards you with healing wounds, particularly soul wounds, rather than bodily ones. You feel as if you were a character in a novel, wandering in its belly.

Ourense is also called The Galician Athens, hometown of the most talented writers born in the Northwest: Blanco Amor, Otero Pedrayo, Risco, Carlos Casares, Méndez Ferrín.

Ourense, which is proud to be provincial, looks onto the River Miño so as to find itself. And it cannot find it because the father Miño walks slowly, erect and proudly. It knows that the future of this land is written in its waters. In order to learn it, you need to walk upon the Roman bridge and stand there staring silently for hours. Then the muses will pay a visit. Ourense makes you relaxed. Ourense makes you fall in love wit it, it is suggestive. Ourense is not the way it is, but the way you remember it.

I have often said that we must open the windows of our city so as to allow the world to see it. This conference is a great opportunity. We thank you for having chosen us and for your wisdom. Ourense needs this kind of event in order to be well-known. Culture is our great heritage: that is our wealth and the good we should export. Remember Valle-Inclán when you return from this conference: "Things are not the way they are, but the way we remember them». We are extremely proud to have you here in Ourense.

Thank you very much. y afable. Piedra a piedra, construye una atmósfera evocadora, cálida en días de niebla, refrescante cuando el sol increpa, adormecida si buscas un poco de sosiego. Piedra a piedra, edifica su futuro entre las figuras y finuras y ficciones que la catedral atesora: un Cristo al que le crece el pelo, un silencio que ensordece, unas vidrieras misteriosas como un cuento de Edgar Allan Poe. Piedra a piedra, se baña en el agua caliente de Las Burgas, ese arcano inexplorado que arranca de lo más íntimo de la ciudad y que otorga, a veces, la recompensa de aliviar heridas, más las del alma que las del cuerpo. Uno tiene la sensación de vagar como un personaje de novela en medio de su vientre.

A Ourense le llaman también la Atenas galaica, lugar de nacimiento de los escritores más talentosos que germinaron en el Noroeste: Blanco Amor, Otero Pedrayo, Risco, Carlos Casares, Méndez Ferrín.

Ourense, orgullosa de ser provinciana, se mira en el Miño para buscarse. Y no se encuentra, porque o pai Miño camina lento y erecto y soberbio. Sabe que en sus aguas está escrito el destino de esta tierra. Para conocerlo, es necesario pasear el puente romano, detenerse durante horas en silente contemplación. Y las musas nos visitan.

Ourense tranquiliza. Ourense enamora, sugestiona. Ourense no es como se ve, sino como se recuerda.

He dicho en numerosas ocasiones que tenemos que abrir las ventanas de nuestra ciudad para que el mundo la conozca. Su congreso es una magnífica ocasión. Agradecemos que nos eligieran y agradecemos su sabiduría. Eventos de esta altura son los que necesita Ourense para ser reconocida. Nuestro gran patrimonio es la cultura: esa es nuestra riqueza y el producto que debemos exportar. Recuerden a Valle-Inclán cuando regresen de este congreso: «Las cosas no son como las vemos sino como las recordamos». Su presencia en Ourense nos llena de orgullo.

Muchas gracias. 